\title{
送電鉄塔用鋼管STKT590溶接熱影響部の 溶融亜鉛めっきぜい化に及ぼす微量ボロンの影響
}

\author{
家澤 徹*・井上 尚志*2 ・平野 攻*3 ・岡沢 亨*4 - 小関 智也*5 \\ Effect of Boron on Liquid Zinc Induced Embrittlement in Heat Affected Zone \\ of STKT590 Steel Tube for Power Transmission Tower \\ Tohru Iezawa, Takashi Inoue, Osamu Hirano, Tohru Okazawa and Tomoya Koseki
}

Synopsis : This paper represents the effect of boron on liquid zinc induced embrittlement in the heat affected zone of STKT590. To determine the susceptibility toward liquid metal zinc induced embrittlement at a fracture time of $400 \mathrm{~s}\left(\mathrm{~S}_{\mathrm{LM}-400}\right), 64$ kinds of carbon steel whose boron content was varied in 4 levels, have been tested by the notched-bar-tensile test method.

$\mathrm{S}_{\mathrm{LM}-400}$ is reduced linearly if a small amount of boron, less than 4 mass ppm, is added. In the case of more than 4 mass ppm of boron, $\mathrm{S}_{\mathrm{LM}-400}$ is minimized to 10 to $20 \%$. Therefore, boron is considered to intensify liquid zinc induced embrittlement, because the ferrite ratio at the grain boundary is reduced.

Additionally, we reconsidered the JIS regression formula of carbon equivalent for susceptibility liquid zinc induced cracking (CEZ). As a result, a modified formula of $\mathrm{CEZ}$ was suggested to revise the JIS formula. This formula has been considered to be effective in predicting resistance to zinc induced cracking in large steel structures.

Key words : carbon steel ; liquid metal embrittlement ; liquid zinc ; boron ; hot galvanizing ; grain boundary ; steel pipe ; electric power transmission tower; regression analysis.

\section{1. 緒言}

送電効率の向上を目的として送電電圧は逐次増大され， 1990年代後半には我国初めての100万ボルト送電 (UHV) が東京電力において営業運転される予定である。この中で 送電鉄塔については従来にない大型鉄塔 (最大約 $950 t /$ 基) となり，設計，鋼材なぼ各方面から長年にわたり検討が行 われた。UHV鉄塔は現在第一次の南北線（柏崎一東山梨） が完了し, 第二次の東西線 (福島一西群馬) が着工されて いる(総重量は約26万t $\mathrm{t}$ 。

鋼材については, 従来の490 540MPa級鋼を590MPa級 に強度を上げ鉄塔の軽量化を図る検討が鋼管, 鋼板, 形鋼, 鍛造フランジ，溶接材料について行われ，「送電鉄塔用新 HT60開発委員会」が1983年に設置された（委員長：藤本盛 久神奈川大学学長, 幹事: 巴ューポレーション, 委員 : 新 日鉄他 12 社)。送電鉄塔は溶接組立後すべて溶融亚鉛めっき が行われるため, めっき中に発生する熱応力および溶接時 の残留応力に起因するすみ肉溶接部の溶融車鉛めっきぜい 化（いわゆる液体金属ぜい化）の対策が鋼材開発の最大の
技術課題であった。一般に鋼材の強度が高いほぼめっきぜ い化が生じやすく、これが溶融带鉛めっき割れ（以下，め っき割れと記す）の発生原因となるためであるが，これに ついてはすでに詳細な研究が行われ1) 5)，1988年「鉄塔用高 張力鋼鋼管G3474-1988」あるいは「鉄塔用高張力鋼鋼材 G3129-1988」等としてJISに制定された。Fig. 1にめっき割 れの一例を示したが旧オーステナイト粒界割れである。

一方，著者らを含む上記開発委員会第1委員会 (鋼管, 鋼



Fig. 1. Appearance of liquid zinc induced cracking occurred at toe of fillet weld.

平成 4 年12月 2 日受付 平成 5 年 5 月14日受理 (Received on Dec.2, 1992 ; Accepted on May 14, 1993)

* (株)巴技研 溶接研究部 (Welding Research Div., Tomoe R\&D, Ltd., 3-4-5 Toyosu Koto-ku Tokyo 135)

* 2 新日本製鉄 (株) 鉄鋼研究所 (Steel Research Laboratories, Nippon Steel Corp.)

* 3 NKK鋼管技術開発部 (Pipe and Tube Technology Developement Dept., NKK Corporation)

* 4 住友金属工業 (株) 和歌山製鉄所 (Wakayama Steel Works, Sumitomo Metal Industries, Ltd.)

* 5 川崎製鉄 (株) 鉄鋼研究所 (Iron \& Steel Research Laboratories, Kawasaki Steel Corp.) 




(a)



(b)
Fig. 2. Details of notched bar tensile test method. Specimen details (a) and stress-temperature diagram (b).
板）は現在も継続され，鉄塔の実製造結果をふまえて各種 の検討を行っているが，この中でUHV鉄塔主柱材として全 面的に使用されているSTKT590（上記JIS•G3474）につい てめっき割れに対する微量ボロンの影響が顕著であること が新たに明らかになった。

本論文では, 微量ボロンについての実験結果とその考察 について述べ,また上記JISのめつき割れに対する鋼材化学 成分の当量式 $r \mathrm{CE} Z 」$ 改訂を提案する。

また，以下に述べる考え方は送電鉄塔のみならず，溶融 亜鉛めっきを行う大型溶接鋼構造物，例えば亜鉛めっき橋 梁等のめっき割れ防止の鋼材研究にも適用できる。

\section{2. 微量ボロンと溶融亜鉛ぜい化}

めっき割れは鋼材を溶融亜鉛に浸せきした時，鋼材に発 生する熱応力および溶接時の残留応力によって溶接熱影響 部の結晶粒界に亜鉛が拡散し，割れが発生すると考えられ


UHV鉄塔の研究過程で既に多くの報告がある。鋼材の亜 鉛ぜい化度の定量方法についても，上記委員会で詳細に検 討され12), JISにも採用されているので, 本研究でもそれを 採用した。すなわち

亜鉛ぜい化度 $\mathrm{S}_{L . M}{ }^{\dagger}$

$$
\left.=\frac{\text { 溶融亜鉛中の切欠破断応力 }}{\text { 亜鉛が無い時の切久破断応力 }} \times 100 （ \%\right)
$$

である。ただし，同一形状の試験片に同一条件で溶接熱影



\section{$2 \cdot 1$ 実験方法および供試鋼}

Fig. 2 に亜鉛ぜい化度 $\mathrm{S}_{\mathrm{LM}}$ ⿸求めるための切欠付き丸棒引 張試験法を示す。試験片の切欠部には加熱温度 $1400^{\circ} \mathrm{C}, 800$ ${ }^{\circ} \mathrm{C} \sim 500^{\circ} \mathrm{C}$ の冷却時間 $8 \mathrm{~s}$ (実際鉄塔溶接の最も早い冷却条 件)の再現溶接熱サイクルを予め与える。引張試験はFig. 2 (b)に示寸試騃条件で行い，鋼種に応じて100～600MPaの 種々の初期応力を負荷して破断時間と破断応力を求める。

$\dagger$ Susceptibility to Liquid Metal Embrittlement
Fig. $3 に \mathrm{~S}_{\mathrm{LM}}$ の試験結果の一例を示すが，鋼種によって $\mathrm{S}_{\mathrm{LM}}$ は大きく差があることがわかる。曲線が上にあるほぼ耐亜 鉛ぜい化度がよいことを示しているが，ここでぜい化度の 具体的数值は，実際のめつき作業も考慮して横軸の破断時 間が $400 \mathrm{~s}$ の時の $\mathrm{S}_{\mathrm{LM}}$, 寸なわち $\mathrm{S}_{\mathrm{LM}-400}$ で鋼種間のぜい化度を 比較した。

供試鋼は微量ボロン（以下Bと記す）を 水準に変化させ ると共に基本成分である C,Mnを実用鋼の範囲で変化させ，



Fig. 3. Relation between fracture time and $S_{L M}$ of various steels by notched bar tensile test. $\mathrm{S}_{\mathrm{LM}}=$ (Fracture stress of zinc coated specimen/Fracture stress of non-coated specimen) $\times 100$.

Table 1. Range of aimed chemical compositions of steels.

\begin{tabular}{c|c|c|c|c}
\hline \multirow{2}{*}{$\begin{array}{c}\text { Thickness } \\
(\mathrm{mm})\end{array}$} & \multicolumn{2}{|c|}{ Chemical compositions (mass\%) } & \multirow{2}{*}{$\begin{array}{c}\text { Number of } \\
\text { charge }\end{array}$} \\
\cline { 2 - 5 } & $\mathrm{C}$ & $\mathrm{Mn}$ & $\mathrm{B}$ & 16 \\
\hline \multirow{2}{*}{20} & $0.10 \sim 0.12$ & $1.3 \sim 1.4$ & 4 levels* & 16 \\
\hline \multirow{2}{*}{12} & $0.06 \sim 0.08$ & $1.6 \sim 1.7$ & 4 levels & 16 \\
& $0.10 \sim 0.12$ & $1.2 \sim 1.3$ & 4 levels & 16 \\
\hline
\end{tabular}

* (1) less than 1 mass ppm, (2) $1 \sim 2$ mass ppm, (3) $2 \sim 3$ mass ppm, (4) $3 \sim 5$ mass ppm 
Table 2. Examples of chemical compositions of steels investigated and experimental results.

\begin{tabular}{|c|c|c|c|c|c|c|c|c|c|c|c|c|c|c|c|c|c|c|c|c|}
\hline \multirow{2}{*}{$\begin{array}{c}\text { Thickness } \\
\text { (mm) }\end{array}$} & \multicolumn{15}{|c|}{ Chemical Compositions* } & \multirow{2}{*}{$\begin{array}{l}\mathrm{Y} . \mathrm{P} \\
\mathrm{MPa}\end{array}$} & \multirow{2}{*}{$\begin{array}{l}\text { T.S } \\
\text { MPa }\end{array}$} & \multirow{2}{*}{$\begin{array}{l}\mathrm{El} \\
\%\end{array}$} & \multirow{2}{*}{$\begin{array}{c}\mathrm{S}_{\mathrm{LM}-400} \\
\quad \%\end{array}$} & \multirow{2}{*}{$\begin{array}{l}\varepsilon_{z c} \\
\%\end{array}$} \\
\hline & $\mathrm{C}$ & $\mathrm{Si}$ & $\mathrm{Mn}$ & $\mathrm{P}$ & S & $\mathrm{Cu}$ & $\mathrm{Ni}$ & $\mathrm{Cr}$ & Mo & V & $\mathrm{Nb}$ & $\mathrm{Ti}$ & $\mathrm{Al}$ & $\mathrm{N}$ & B & & & & & \\
\hline \multirow{8}{*}{12} & 0.078 & 0.21 & 1.47 & 0.018 & 0.004 & 0.01 & 0.01 & 0.01 & 0.01 & 0.038 & 0.048 & 0.015 & 0.019 & 0.0018 & 0.6 & 482 & 593 & 35 & 65 & 4.1 \\
\hline & 0.076 & 0.21 & 1.45 & 0.017 & 0.004 & 0.01 & 0.01 & 0.01 & 0.01 & 0.038 & 0.047 & 0.014 & 0.019 & 0.0018 & 2.7 & 512 & 622 & 32 & 21 & 2.5 \\
\hline & 0.074 & 0.22 & 1.44 & 0.020 & 0.004 & 0.01 & 0.01 & 0.01 & 0.01 & 0.040 & 0.053 & 0.018 & 0.021 & 0.0017 & 3.1 & 516 & 628 & 34 & 14 & 1.7 \\
\hline & 0.074 & 0.22 & 1.43 & 0.020 & 0.004 & 0.01 & 0.01 & 0.01 & 0.01 & 0.039 & 0.052 & 0.017 & 0.021 & 0.0017 & 4.9 & 522 & 633 & 32 & 11 & 1.3 \\
\hline & 0.120 & 0.20 & 1.27 & 0.018 & 0.004 & 0.01 & 0.01 & 0.01 & 0.01 & 0.029 & 0.047 & 0.017 & 0.018 & 0.0018 & 0.3 & 526 & 625 & 33 & 76 & 4.4 \\
\hline & 0.118 & 0.20 & 1.27 & 0.018 & 0.004 & 0.01 & 0.01 & 0.01 & 0.01 & 0.029 & 0.047 & 0.017 & 0.018 & 0.0017 & 2.4 & 525 & 648 & 33 & 40 & 2.9 \\
\hline & 0.118 & 0.20 & 1.27 & 0.018 & 0.004 & 0.01 & 0.01 & 0.01 & 0.01 & 0.037 & 0.045 & 0.016 & 0.018 & 0.0022 & 4.5 & 510 & 625 & 32 & 20 & 1.3 \\
\hline & 0.116 & 0.20 & 1.26 & 0.018 & 0.004 & 0.01 & 0.01 & 0.01 & 0.01 & 0.037 & 0.044 & 0.016 & 0.018 & 0.0018 & 6.1 & 519 & 636 & 32 & 12 & 1.1 \\
\hline
\end{tabular}

* mass ppm for B and mass\% for other elements

Table 1に示す 64 鋼種とした。いずれも $200 \mathrm{~kg} \sim 500 \mathrm{~kg}$ の真 空溶解を行い, 小型圧延機により, 制御圧延, 制御冷却の 現場製造条件を再現した。すなわち, UO鋼管の代表として 板厚 $20 \mathrm{~mm}, \mathrm{ERW}$ 鋼管の代表として板厚 $12 \mathrm{~mm}$ の鋼板に圧 延した。

Table 2 に具体的化学成分, 機械的性質および $\mathrm{S}_{\mathrm{LM}-400}$ の一 例を示した(表中の $\varepsilon_{\mathrm{zc}}$ は後述)。Bはいずれも湿式分析を行 ったがほぼ目標の值を得ておりまた機械的性質もJISを満 足している。

\section{$2 \cdot 2$ 実験結果}

Fig. 4 に64鋼種についてのB量と $\mathrm{S}_{\mathrm{LM}-400}$ の関係を示す。 $\mathrm{S}_{\mathrm{LM}-400}$ はC, Mn等の多少の変化にかかわらず, B量 4 mass ppmまでほぼ直線的かつ急激に低下し, B量4mass ppm以 上では10〜20\%の低值にほぼ収れんする。すなち4mass ppm 以下の微量Bが, 覀鉛ぜい化に対して極めて大きな影響を及 ぼすことが明瞭である。

$\mathrm{S}_{\mathrm{LM}-400}$ の絶対值と実際のめつき割れとの関係については, 熱影響部に母材の降伏応力に相当する応力が付加されても $\mathrm{S}_{\mathrm{LM}-400} \geqq 42 \%$ で亜鉛割れが発生しないことが明らかにされ ている1)。従ってB量が2mass ppm以下ではこの条件をほぼ

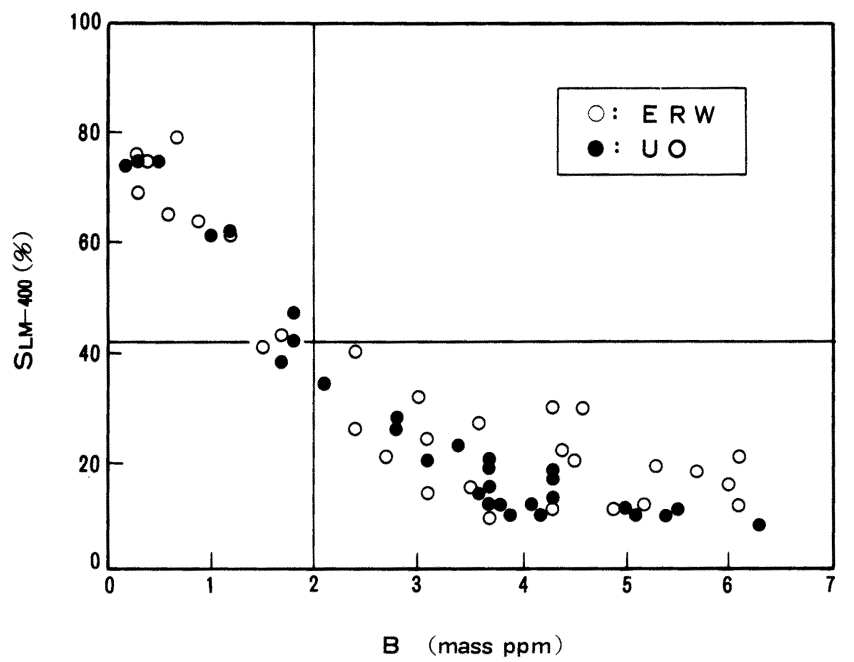

Fig. 4. Effect of boron on measured value of $\mathrm{S}_{\mathrm{LM}-400} \cdot \mathrm{S}_{\mathrm{LM}-400}$ means $\mathrm{S}_{\mathrm{LM}}$ at fracture time of $400 \mathrm{~s}$.

ERW:electric resistance welded steel tubes,

UO : UO-formed steel tubes.
満足できる。

Fig. 4をさらに確認するため現場溶解鋼で実際の鉄塔に使 用された13鋼種について試験を行った。この13鋼種はいず れもBが2mass ppm以下であり, Fig. 4の横軸に対する分布 範囲が小さいが，64鋼種の小型溶解鋼の結果とよく一致し た。ここで付記したいのは, 従来から現場溶解の鋼材にBは 添加していないことである。従って, 大部分の鋼材はBが2 mass ppm以下であるが， $\mathrm{Si}, \mathrm{Mn}$ 等の合金鉄, あるいは転 炉の炉壁等から不純物として入る場合があり，時として2mass ppm以上の場合もあり得るのが実状であった。今回，めっ き割れの鋼材対策として2mass ppm以下が必要条件である ことが明確になったので，各製鉄メーカーは製鋼段階でこ の管理を充分に行うことを決定し，またこれが可能である ことも確認された。

一方, 微量Bによる $\mathrm{S}_{\mathrm{LM}-400}$ の低下の原因を考える場合, $\mathrm{B}$ は周知のように烧入性増加の元素であり，水素による溶接 割れ（低温割れ）の場合と同じく溶接熱影響部の硬さの増 加の影響を考えなければならない。Fig. 5にB量と再現熱影 響部の硬さ (ボンド部硬さ) の関係を示した。ばらつきは 大きいがB量の増加に伴い硬さが全般的に増加する傾向にあ る。しかし3mass ppm以下の場合は，その影響は明瞭とは 言えない。

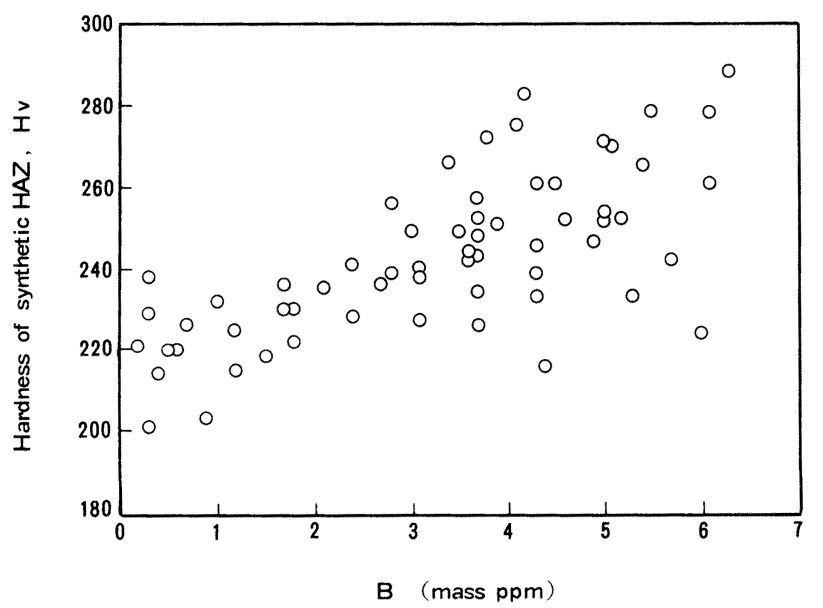

Fig. 5. Relation between boron content and hardness of synthetic HAZ. 


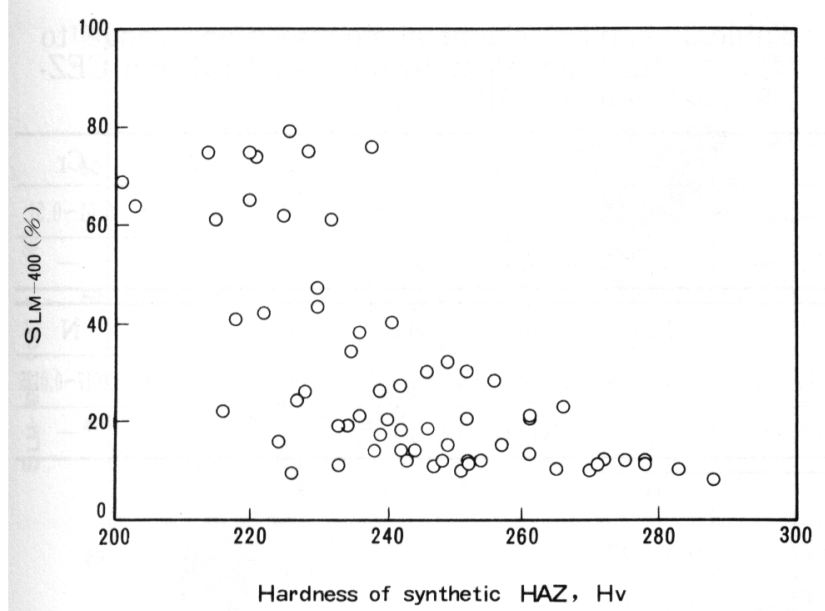

Fig. 6. Relation between hardness of synthetic HAZ and measured value of $\mathrm{S}_{\mathrm{LM}-400}$.

Fig. 6 に硬さと $\mathrm{S}_{\mathrm{LM}-400}$ との関係を示す。 $240 \mathrm{HVW上では}$ 明らかに $\mathrm{S}_{\mathrm{LM}-400}$ が低下するが，実際の鉄塔の熱影響部の硬 さは大部分が220〜240HVであり,この範囲では $\mathrm{S}_{\mathrm{LM}-400}$ と硬 さの相関は認められない。

従って微量 $\mathrm{B} よ る \mathrm{~S}_{\mathrm{LM}-400}$ の低下は別の原因を考えなけれ ばならず，これについては次章で述べる。

\section{3. 溶融亚鉛ぜい化と結晶粒界フェライト占有率}

$\mathrm{S}_{\mathrm{LM}-400}$ と結晶粒界フェライト占有率 (以下，フェライト 占有率と記す）は正の相関関係があることは鉄塔の研究と は別に一連の亜鉛めっき橋梁の研究において著者らの一部 が既に報告している10)11)。

ここでいう粒界フェライトとは，溶接熱影響部の組織の 中で旧オーステナイト粒界に析出する初析フェライト及び 上部ベイナイトを意味し，また粒界フェライト長さの粒界 長さ全体に対する比率をつエライト占有率と定義している。 また,この研究で $\mathrm{S}_{\mathrm{LM}-400}$ が50\%以上, フェライト占有率 $60 \%$ 以上の鋼にBを3〜 mass ppm添加した場合, $\mathrm{S}_{\mathrm{LM}-400}$ おむ゙ フェライト占有率が大きく低下すると報告している。しか し,ここでは微量Bの影響についての詳細なデータは得られ ていない。

この知見に基づき, 前章で得られた鉄塔用鋼材の微量 B $\mathrm{S}_{\mathrm{LM}-400}$ の関係の原因について検討した。

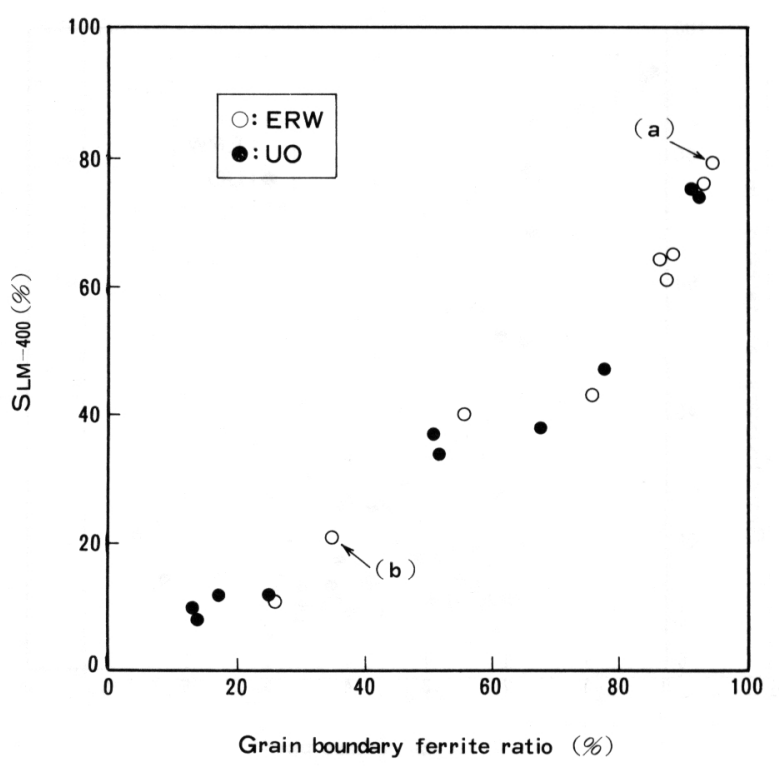

Fig. 7. Relation between grain boundary ferrite ratio and measured value of $\mathrm{S}_{\mathrm{LM}-400}$. Microstructures of (a) and (b) are shown in Fig. 8.

Table 2に化学成分の一例を示した今回の64鋼種の中から 約 20 鋼種を選出し, $\mathrm{S}_{\mathrm{LM}-400}$ とフェライト占有率の関係を Fig. 7 に示した。両者は直線に近い相関を示し, 微量Bの影響が 前述の硬さでは説明できないが，フェライト占有率でよく 説明できることがわかる。図中 $\mathrm{a}, \mathrm{b} 2$ 鋼種についての組織を Fig.8に示した。

Fig.9に前述の約 20 鋼種についてのB量とフェライト占有 率との関係を示すが，両者にはよい相関が認められる。フ エライト占有率は，粒界近傍での焼入性（以下，粒界焼入 性と記す）と反比例の関係を示すものであり，鉄塔用鋼材 STKT590ではBの影響を直線的に受けることが明瞭である。

このフェライト占有率に大きな影響を及ぼす粒界焼入性 が従来の焼入性の回帰式（例えばCeq式，DI式）で決まら ない理由は, 焼入性の回帰式は多くの場合粒界, 粒内を問 わず平均的な焼入硬さによって決められ，少量の粒界フ工 ライトの析出は硬さにほとんど影響しないためである。

前述のように亜鉛ぜい化は粒界への亜鉛の拡散侵入によ って生ずるが，粒界フェライトがこの拡散侵入を抑制する と推定される。


(a) $\mathrm{S}_{\mathrm{LM}-400}: 79 \%$, Grain boundary ferrite ratio : $95 \%$ (b) $\mathrm{S}_{\mathrm{LM}-400}: 21 \%$, Grain boundary ferrite ratio : $35 \%$

Fig. 8. Examples of microstructures of synthetic HAZ. 


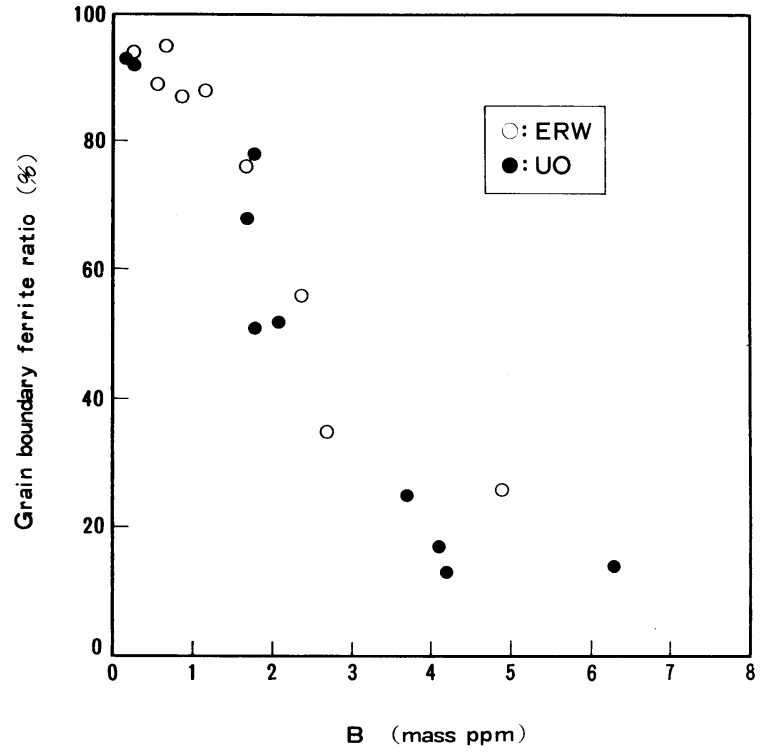

Fig. 9. Relation between boron content and grain boundary ferrite ratio.

ERW:electric resistance welded steel tubes, UO : UO-formed steel tubes.

\section{4．溶融亜鉛ぜい化感受性当量CEZ式の 再検討}

めつき割れを防止するためには $\mathrm{S}_{\mathrm{LM}-400} \geqq 42 \%$ が必要条件 である。しかし，この值による鋼材管理は特殊な試験設備 を必要とするため現実的でない。そこで，鋼材の化学成分 から $\mathrm{S}_{\mathrm{LM}-400}$ を推定し管理することを目的に設定されたのが 現在の溶融带鉛ぜい化感受性当量CEZ式 (JIS) である。同 式は $\mathrm{S}_{\mathrm{LM}-400}$ の実測值に対する鋼材成分の影響を重回帰計算 により定量化し導き出されたものであるが，今回， $\mathrm{S}_{\mathrm{LM}-400}$ に対する微量ボロンの顕著な影響が明らかにされたため, その見直しが必要になった。以下, 新たな式CEZ $\bmod ^{*}$ (*modify) の検討結果を述べる。

\section{$4 \cdot 1$ 適用化学成分範囲}

前章に述べた64鋼種のみでは合金元素の種類，添加量の 点で変動要因が少なく,CEZmod式の検討には不十分である。 そこで, 現CEZ式の検討に使用した鋼の中から Bが比較的少 ない122鋼種（B：10 mass ppmまで）を加えた。

本回帰計算に用いた鋼の化学成分範囲をTable 3 に示し た。CEZ式の成分範囲と唯一大きく異なる点はB量で, CEZ 式がBの最大含有量 40 mass ppmであるのに対し, 本回帰計 算ではこれを10mass ppmとした点である。

なお，上記122鋼種もBが4 10mass ppmの場合, Fig.4 同じく他の合金元素の添加量によらず $\mathrm{S}_{\mathrm{LM}-400}$ が10 20\%の 実験結果であった。従って，Bが10mass ppmまでを一次式 で重回帰計算するとBの係数が不正確になることが予測され る。なお，Bが $4 \sim 10$ mass ppmの鋼種（34鋼種）を除いて， $\mathrm{B} \leqq 4$ mass ppmの鋼だけで回帰計算すると相関係数が 0.918 と低くやや信頼性に欠けると考えた。そこでBが4〜10mass ppmの鋼はBをすべて4mass ppmとして計算した。
Table 3. Applied chemical compositions range to the equivalent formula of $\mathrm{CEZ}$ and CEZ mod, and JIS spec..

\begin{tabular}{l|c|c|c|c|c|c}
\hline & $\mathrm{C}$ & $\mathrm{Si}$ & $\mathrm{Mn}$ & $\mathrm{Cu}$ & $\mathrm{Ni}$ & $\mathrm{Cr}$ \\
\hline CEZ,CEZmod & $0.020 \sim 0.120$ & $0.17 \sim 0.33$ & $1.23 \sim 1.95$ & $0.01 \sim 0.55$ & $0.01 \sim 0.58$ & $0.01 \sim 0.51$ \\
\hline JIS spec. & $\leqq 0.12$ & $\leqq 0.4$ & $\leqq 2.0$ & - & - & - \\
\hline \hline & $\mathrm{Mo}$ & $\mathrm{V}$ & $\mathrm{Nb}$ & $\mathrm{Ti}$ & $\mathrm{Al}$ & $\mathrm{N}$ \\
\hline CEZ, CEZmod & $0.01 \sim 0.38$ & $0.002 \sim 0.115$ & $0.002 \sim 0.057$ & $0.002 \sim 0.030$ & $0.011 \sim 0.043$ & $0.0017 \sim 0.0125$ \\
\hline JIS spec. & - & $\mathrm{Nb}+\mathrm{V} \leqq 0.15$ & - & - & - \\
\hline \hline & $\mathrm{B}$ & \\
\hline CEZ & $0.1 \sim 40$ \\
\hline CEZmod & $0.1 \sim 10$ \\
\hline JIS spec. & - \\
* mass ppm for B and mass\% for other elements
\end{tabular}

また, Bを多次式で回帰することはCEZ式に変換する際に 精度低下が避けられず，一次问帰とした。

\section{$4 \cdot 2$ 重回帰分析結果}

現在のCEZ式はJISにも示されている次のとおりである。 $\mathrm{S}_{\mathrm{LM}-400}=424-667 \mathrm{C}-25 \mathrm{Si}+\left(95 \mathrm{Mn}^{2}-342 \mathrm{Mn}\right)$

$$
+354 \mathrm{~S}-230 \mathrm{~V}-273 \mathrm{Nb}-130 \mathrm{Ti}+\left(188 \mathrm{Cr}^{2}-198 \mathrm{Cr}\right)
$$$$
-72 \mathrm{Mo}-6000 \mathrm{~B}
$$

Sはプラスの効果が得られたが,じん性などへの悪影響から 積極的に添加量を増加できないことから $\mathrm{S}=0.005 \sim 0.007$ mass\%として，定数に+2を加算した。

また $\mathrm{Cr}, \mathrm{Mn}$ 項を直線近似した一次式から，当量式に算 術変換し，めっき割れ防止条件である $\mathrm{S}_{\mathrm{L}, \mathrm{M}-400} \geqq 42 \%$ を加え， 次の当量式を得ている。

$\mathrm{CEZ}=\mathrm{C}+\mathrm{Si} / 27+\mathrm{Mn} / 12+\mathrm{V} / 3+\mathrm{Nb} / 2.5+\mathrm{Ti} / 5+\mathrm{Cr} / 6$

$+\mathrm{Mo} / 9+9 \mathrm{~B} \leqq 0.28$ mass $\%$

一方，前述のようにBをすべて4mass ppm以下とした186 鋼種についての重回帰結果は次のとおりである。

$$
\begin{aligned}
& \mathrm{S}_{\mathrm{LM}-400}=201-370 \mathrm{C}-22 \mathrm{Si}-51 \mathrm{Mn}-35 \mathrm{P}+33 \mathrm{~S} \\
& -28 \mathrm{Cu}-22 \mathrm{Ni}-87 \mathrm{Cr}-123 \mathrm{Mo}-275 \mathrm{~V}-182 \mathrm{Nb}-82 \mathrm{Ti} \\
& +24 \mathrm{Al}+1700 \mathrm{~N}-155000 \mathrm{~B}
\end{aligned}
$$

(3) 式と同様に $\mathrm{S}_{\mathrm{LM}} \geqq 42 \%, \mathrm{~N}$ は 30 mass ppm として定数 に+5を加算し，当量式に変換すると（5)式になる。なお， P, S, Alは（4）式における寄与率が低く，またこれらの係数 が小さく添加量も少ないので削除できる。

$$
\begin{aligned}
& \text { CEZmod }=\mathrm{C}+\mathrm{Si} / 17+\mathrm{Mn} / 7.5+\mathrm{Cu} / 13+\mathrm{Ni} / 17 \\
& +\mathrm{Cr} / 4.5+\mathrm{Mo} / 3+\mathrm{V} / 1.5+\mathrm{Nb} / 2+\mathrm{Ti} / 4.5 \\
& +420 \mathrm{~B} \leqq 0.44 \mathrm{mass} \%
\end{aligned}
$$

(5) 式はBの係数が( 3 )式に比べて大きく増加している のが特徵である。またFig.10に ( 4 ) 式の計算値と実測值と

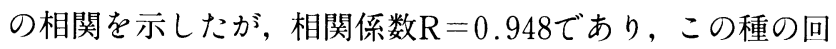
帰式としては妥当な数值であると考える。

Fig.11にCEZmod と $S_{\mathrm{LM}-400}$ の関係を示した。B $>2$ mass ppmの場合, 規定值であるCEZmod $\leqq 0.44 \mathrm{mass} \%$ を満足す 


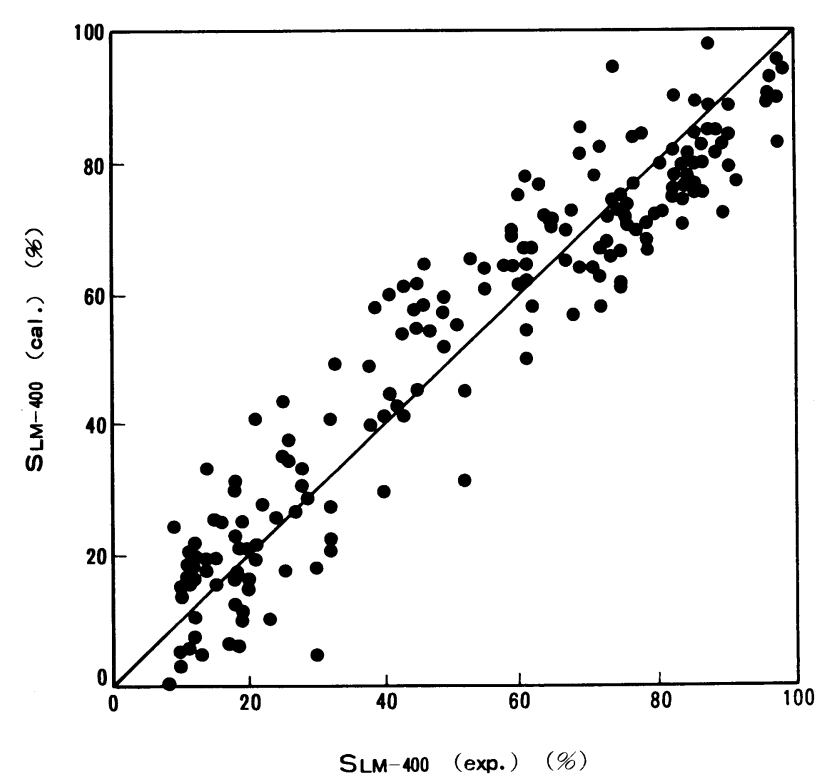

Fig. 10. Comparison of the measured value with the calculation value of $\mathrm{S}_{\mathrm{LM}-400}$.

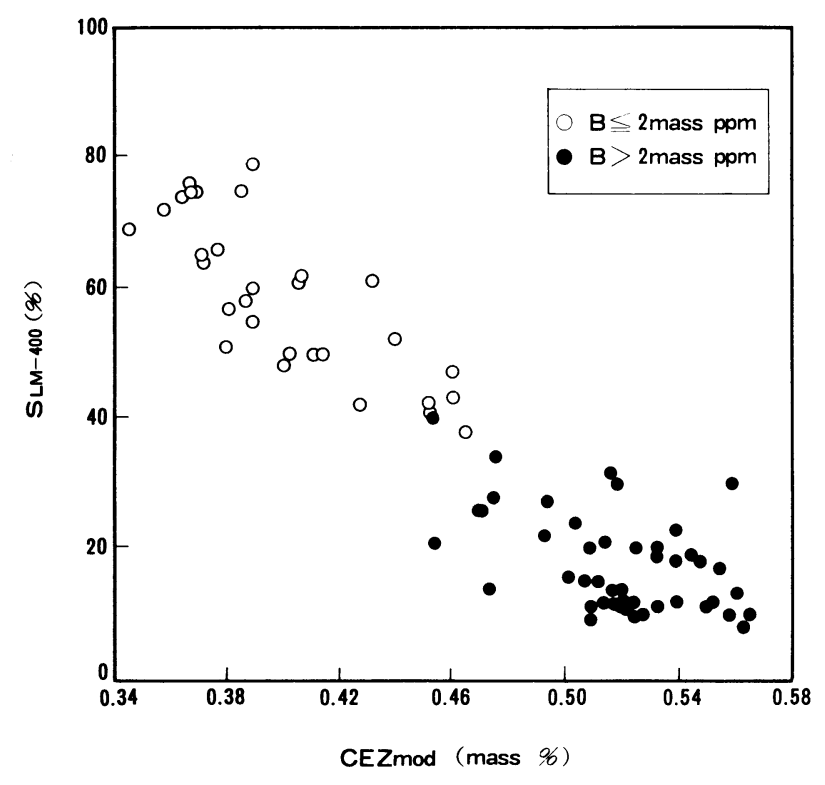

Fig. 11. Relation between calculation CEZmod values and measured $S_{L M-400}$ values.

ることはできず，また $\mathrm{S}_{\mathrm{LM}-400}$ もすべて $42 \%$ 以下となる。一 方 $\mathrm{B} \leqq 2 \operatorname{mass} \mathrm{ppm}$ 以下の場合は, $\mathrm{CEZ} \bmod \leqq 0.44 \operatorname{mass} \%$ を ほぼ確保でき (CEZmod>0.44mass\%の場合が少数あるが， これは試験溶解でMn等を特に高くした場合である)，この 条件では $\mathrm{S}_{\mathrm{LM}} \geqq 42 \%$ を得ている。また $\mathrm{B}$ 量にかかわらず一貫 してCEZmod と $\mathrm{S}_{\mathrm{LM}-400}$ の相関性もよく本式の妥当性が示さ れていると考える。

Fig.12にCEZと $\mathrm{S}_{\mathrm{LM}-400}$ の関係を示した。B $>2$ mass ppm の場合でもCEZの規定值 $0.28 \mathrm{mass} \%$ 以下を満足できる場合 が多いが， $\mathrm{S}_{\mathrm{LM}} \geqq 42 \%$ は確保できない。また $\mathrm{B} \leqq 2$ mass ppm の場合はほぼ $\mathrm{S}_{\mathrm{LM}} \geqq 42 \%$ を得ているが(例外は上述と同じく， $\mathrm{Mn}$ 等を特に高くした場合), 全体的にCEZと $\mathrm{S}_{\mathrm{LM}-400}$ の相関

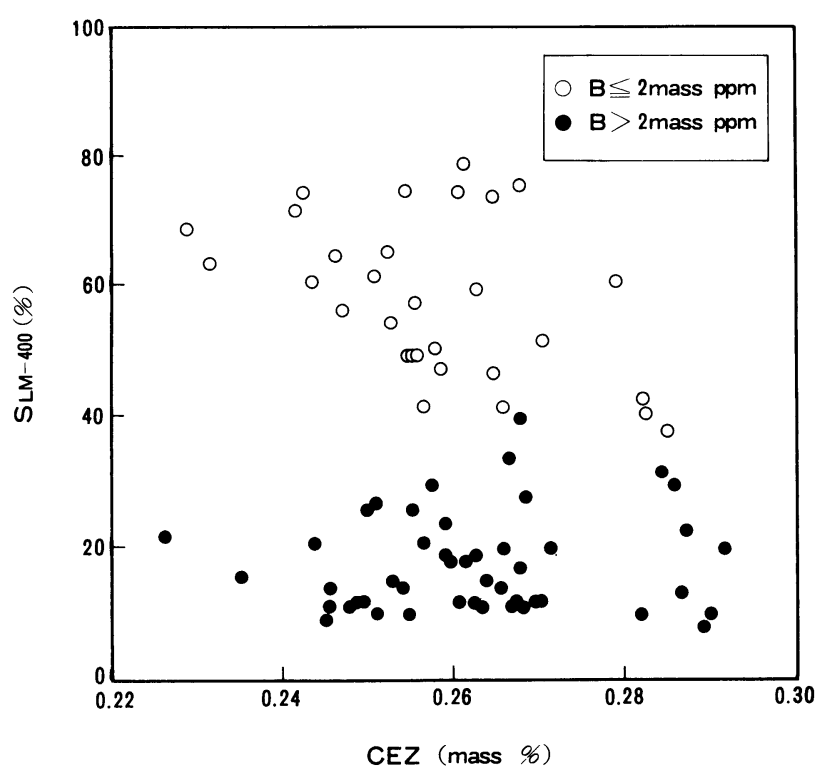

Fig. 12. Relation between calculated $\mathrm{CEZ}$ values and measured $\mathrm{S}_{\mathrm{LM}-400}$ values.

はよくない。

以上, 微量Bの影響の結果から, 現在の JIS ・ CEZ式を CEZmod式に改訂することを提案する。

\section{5. 溶接熱影響部の限界ひずみ}

めつき割れについては鉄塔構造の面から各種の検討がな されている。実際に割れの発生しやすい箇所は鋼管厚に対 して比較的厚いガセットプレートをすみ肉溶接した部位で あり，板厚比が大きいほぼ割れが発生しやすい。

東京電力ではめっき浸せき時に熱応力により発生する局 部ひずみが板厚比に伴って大きくなるとの見解から, 熱弾 塑性解析によりすみ肉溶接止端部の局部ひずみを算出し, 鋼材のひずみによる評価法が検討された12)。著者らの前述の 応力法々東京電力のひずみ法は, いずれも $450^{\circ} \mathrm{C} \sim 470^{\circ} \mathrm{C}$ の 垔鉛中での評価方法で, 破断応力あるいは割れ発生ひずみ の低下はこの温度における粒界ぜい化という同一の原因に よる。また応力法でも切久底部は絶対量は小さいが塑性変 形が生じる。従って両方法は基本的には差異はないと考え る。さらに, 橋梁の研究において溶融亜鉛中における鋼材 の破断までの塑性曲げ角度と $\mathrm{S}_{\mathrm{LM}-400}$ は相関があることを著 者らの一人が報告している13)。

以下応力法とひずみ法の比較についての実験結果および 後述の限界ひずみとCEZmodとの相関について述べ。

熱影響部のひずみの検討は, 東京電力の方法と同じく板 厚 $7 \mathrm{~mm}$, 平行部長さ $60 \mathrm{~mm}$, 幅 $19 \mathrm{~mm}$ の引張試験片を炉加 熱により試験片全体に溶接熱影響部を再現し ${ }^{\dagger 2}, 450^{\circ} \mathrm{C}$ の亜

$† 2$ 加熱炉の関係で加熱温度 $1250^{\circ} \mathrm{C}$, 保持時間 $5 \mathrm{~min}, 800^{\circ} \mathrm{C} \sim 500^{\circ} \mathrm{C}$ の冷却時 間を15sとした。15sとしたのは, この加熱条件で, 実際の鉄塔すみ肉溶 接部の組織, 硬さに合わせたことによる。 
鉛中で引張荷重を加え，除荷法によりき裂が発生しない最 大ひずみを限界ひずみ $\left(\varepsilon_{\mathrm{zc}}\right)$ とし，この $\varepsilon_{\mathrm{zc}}$ で各種の検討を 行った。

Fig.13に $\mathrm{S}_{\mathrm{LM}-400}$ と $\varepsilon_{\mathrm{zc}}$ の関係を示す。両者では熱影響部の 再現条件も異なり低 $S_{\mathrm{LM}-400}$, 低 $\varepsilon_{z c}$ の範囲ではばらつくが, 実際の鋼の $\mathrm{S}_{\mathrm{LM}-400} \geqq 42 \%$ の範囲では比較的相関性がよく予 想どおりの結果である。東京電力では前述の熱弾塑性解析 による局部ひずみの算出から， $\varepsilon_{\mathrm{zc}} \geqq 2 \%$ 目標にしている が, 図のとおり, $\mathrm{S}_{\mathrm{LM}} \geqq 42 \%$ ばはこの目標をほぼ満足してい る。 $\mathrm{S}_{\mathrm{LM}} \geqq 42 \%$ は, 前述のように母材の降伏応力に相当する 応力が付加された拘束継手試験から割れ限界の $\mathrm{S}_{\mathrm{LM}-400}$ を求 めたものであり ${ }^{122)}$ ，この拘束継手試験でも熱影響部には局

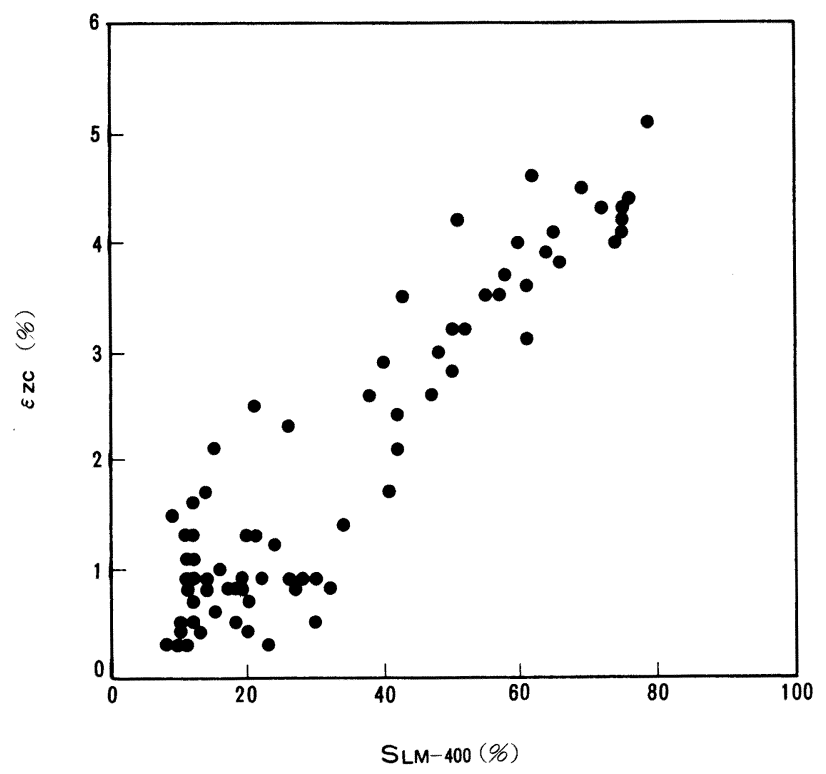

Fig. 13. Relation between measured values of $\mathrm{S}_{\mathrm{LM}-400}$ and $\varepsilon_{\mathrm{zc}}$. $\varepsilon_{\mathrm{zc}}$ means the maximum strain where cracking does not occur in molten zinc.

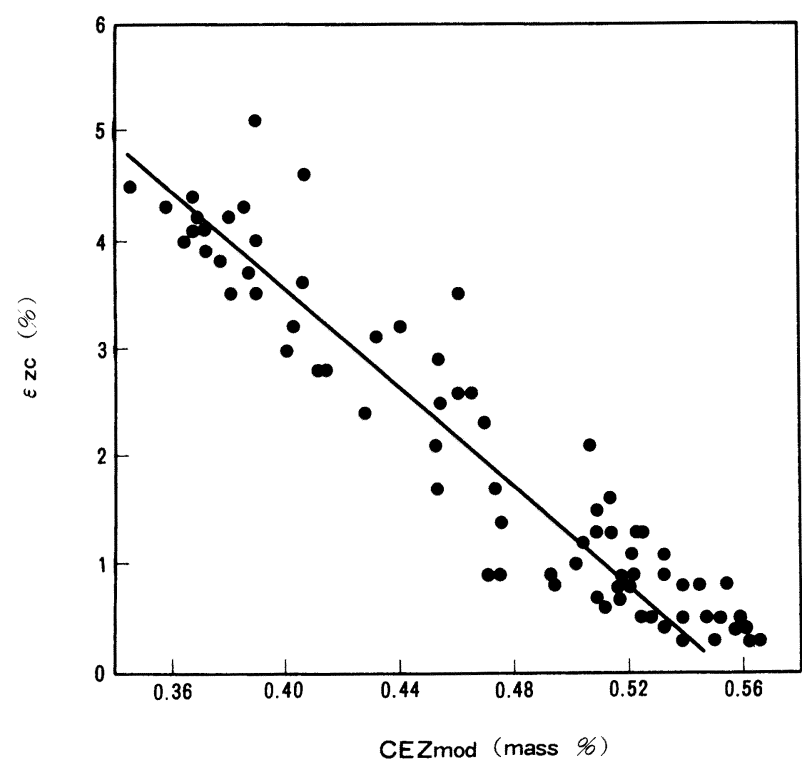

Fig. 14. Relation between calculated CEZmod values and $\varepsilon_{\mathrm{zc}}$.
部的塑性ひずみが生ずる。従って $\mathrm{S}_{\mathrm{LM}-400}=42 \%$ と $\varepsilon_{\mathrm{zc}}=2 \%$ は基本的にはほぼ一致するものと考える。

Fig.14にCEZmod $と \varepsilon_{\mathrm{zc}}$ の関係を示すが相関係数 $\mathrm{R}=0.939$ で比較的よく一致している。またCEZmod $\leqq 0.44 \operatorname{mass} \%$ が 規定でありこれにより $\varepsilon_{\mathrm{zc}} \geqq 2 \%$ も満足できることがわか る。

以上，東京電力で検討された限界ひずみでの鋼材評価法 も, 従来の応力法による $\mathrm{S}_{\mathrm{LM}-400}$, さらにはCEZmodとよく 一致することが確認された。

\section{6. 総括}

送電鉄塔用鋼管STKT590の溶融垔鉛めっきぜい化に及ぼ す微量Bの影響について述べた。

すなわち微量Bの影響がきわめて大きいことを定量的に把 握し，この結果は送電鉄塔のみならず，亜鉛めっき橋梁等 の大型鋼構造のめっき割れ防止技術をさらに一歩進めたも のと確信する。

また, Bがめっきぜい化を促進する原因は溶接熱影響部の 粒界フェライト占有率の減少によることを明らかにすると 共に, 化学成分によるめっき割れ防止の重回帰式CEZ(JIS) を再検討し, 新たな重回帰式CEZmod式を導出し, JIS改訂 を提案した。

また本研究で西鉛割れの評価法として採用した破断応力 比と東京電力で検討された限界ひずみによる評価法はよく 一致することも確認した。

本研究は, 送電鉄塔用新HT60開発委員会第一委員会とし て行ったものであり, 終始, 具体的御指導を得た委員長： 藤本盛久博士 [神奈川大学学長］および幹事：金沢正午博 士 [(株)巴技研取締役社長]ならびに著者ら以外の各委員 に深謝申し上げる。また熱心に御討議をいただいた東京電 力送変電建設本部殿に御礼申し上げる。

\section{文献}

1）送電鉄塔用新HT60開発委員会（代表：藤本盛久, 金沢正午）： JSSC, 21 (1985) 221, p.11

$2 ）$ 金沢正午, 広木光雄, 家沢 徹:巴組鐵工所技報, (1988) 1, p.28

3 ）例えば, 武田鉄治郎, 粟飯原周二, 山户一成, 権藤 永：鉄 2 鋼, 68 (1982), S1264

4 ）例えば, 生駒 努, 畕山耕太郎, 小指軍夫, 新倉正和, 山本定弘： 鉄々 鋼, 69 (1983), S679

5 ）例之ば，小関智也，杉江英司，志賀千晃，上田修三，松山隼也， 竹内幸正：鉄と鋼，70 (1984), S1382

6 ) 菊池昌利, 家沢 徽：日本造船学会論文集, 149 (1981), p.309

7 ) 菊池昌利, 家沢 徹：材料, 31 (1982), p.271

8 ) 菊池昌利：鉄々鋼, 68 (1982), p.1870

9 ）武田鉄治郎, 金谷 研, 山戸一成：鉄と鋼, 72(1986), S1532

10）金谷 研, 井上尚志, 山戸一成, 今井晴夫：材料とプロセス, 1 (1988), p.494

11）山下達雄, 家沢 徹, 金沢正午, 井上尚志, 金谷 研 : 巴組鐵工 所技報, (1991) 4, p.56

12）東京電力送变電建設本部：社内報告, (1991), (私信)

13）金谷 研, 井上尚志, 今井晴夫, 船津裕二：材料とプロセス, 3 (1990), p.1395 